\section{Tegninger af \\ Hermann Ernst Freund blandt N.L. Høyens papirer}

Af mag.art. Ejner Johansson

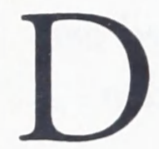

en danske billedhugger Hermann Ernst Freund (17861840) kan synes ligesom "indeklemt” mellem et par umådelig produktive kolleger: den noget ældre Thorvaldsen og den lidt yngre H.W. Bissen.

Medens statuer, buster og relieffer udgik i en lind strøm fra de to sidstes værksteder, er Freunds oeuvre som billedhugger langt mere beskedent af omfang - også mere uegalt.

Det mindre omfang har nok både indre og ydre årsager; blandt de sidste at han kom sent i gang. Freund var 31 år gammel, før han vandt Kunstakademiets store guldmedalje med det tilhørende rejsestipendium, og da han døde i 1840, var han kun 53 år, hvorimod Thorvaldsen nåede 74, Bissen omtrent 70 år og begge bevarede deres arbejdskraft til det sidste.

Til gengæld satte Freund sit afgørende mærke på flere områder end skulpturen, blandt andet på den danske møbeltradition og på medaljekunsten. Her skal gøres opmærksom på et materiale i Det Kongelige Bibliotek, hidtil ukendt, som vedrører hans indsats på disse to områder.

Freund var født i Nordtyskland, i nærheden af Bremen; hans far var dyrlæge, han selv blev udlært som smed hos en onkel i København, 1811 blev han dansk borger. Smederiet har dog næppe været hans store kærlighed; ved siden af smedefaget lærte han sig at skære stempler og var en tid beskæftiget ved Mønten i København. Som smedelærling gik han i akademiets ornamentklasse, og efterhånden fandt Freund ud af, at han ville være billedhugger - billedhugger og medaljør. 1817 drog han på den klassiske studietur til Italien, hvor han en halv snes år arbejdede i Thorvaldsens romerske værksteder.

Først i efteråret 1828 kom Freund tilbage til København. Han gik hjem fra Italien til Danmark på sine ben næppe for motionens skyld, men Kunstakademiets romerske stipendiater levede i evig pengemangel, så fødderne har været det eneste overkommelige transportmiddel til hjemturen. Tilmed lagde han vejen hjem over Paris, München og Berlin.

Aret efter blev han udnævnt til professor i billedhuggerkunst ved Kunstakademiet og fik samtidig anvist værksted og bolig i Materialgården ved Frederiksholms Kanal, hvor blandt andre Johannes Wiedewelt før ham havde haft atelier. Til at gøre arbejdsrum og boligen istand fik han den efter datidens forhold betydelige sum af 4000 rbdl.; det var nok Jonas Collin, der også her gjorde sin indflydelse gældende - og så tog Freund fat.

Til en begyndelse dog ikke så meget på billedhuggeriet - kunderne stod ikke ligefrem i kø - som på at forvandle stadens civile materialgård til en slags drøm om det Italien, han så ugerne havde forladt. 
Sammen med unge kunstnere som Constantin Hansen og Georg Christian Hilker dekorerede og malede han sine stuer "på pompejansk" $\mathrm{i}$ rene røde, gule og grønne farver efter forbilleder fra udgravningerne af oldtidshuse i Pompeji og Herculanum. Stuerne fyldte han efterhånden med møbler, han selv havde tegnet - nu der var penge til sådan en luksus. De blev også formet efter antikke eksempler på græske og romerske relieffer, på vasebilleder og fund fra de to oldtidsbyer, som forsvandt ved Vesuvs udbrud i året 79. Inden hjemrejsen havde han sammen med Bissen besøgt Syditalien, Sicilien og modtaget stærke indtryk netop fra Herculanum og Pompeji. Hvad den tidligere håndværkssvend her så af oldtidens husgeråd og lignende, gjorde stort indtryk på ham

Freunds bolig var færdig ved midten af 1830rne og vakte stor opsigt i datidens København. Folk nøjedes ikke med at kigge ind gennem Materialgårdens vinduer, det velhavende, italiensbegejstrede borgerskab ville have deres stuer dekoreret på samme vis som professorens i den nye farverige pompejanske stil, som kulminerede få år senere i Thorvaldsens museum på den anden side af kanalen.

De freundske møbler vakte lignende opsigt. Også de kopieredes og efterlignedes - først og fremmest i det kunstnermiljø, som havde et bevidst forhold til antikken; Bissen, Høyen, Bindesbøll, Hilker, Constantin Hansen og mange med dem sad på "freundske" klismos-stole, som var de gamle grækere og ikke Christian VIIIs danske undersåtter. Professorboligen ved Frederiks- holms Kanal blev et af højdepunkterne i det nittende århundredes danske interiørkunst, det har blandt andre dr. Mirjam Gelfer-Jørgensen understreget i Herculanum paa Sjalland, bogen om den danske nyantiks møbler, ${ }^{1}$ Kunstindustrimuseets tidligere direktør, Erik Lassen, har påpeget, at Freunds hjem "spillede en rolle indenfor billedkunstens verden, som kan jævnføres med det Heibergske hjems betydning for den selskabelige åndsdannelse."2

Freunds møbler kan i dag hovedsagelig ses på Frederiksborgmuseet og på Kunstindustrimuseet i København. De er studeret og beskrevet, blandt andet i Herculanum paa Sjalland, hvor man også gør opmærksom på, at der med en beskeden undtagelse hverken findes udkast eller tegninger til dem fra Freunds hånd.

Men en god del af hans møbelskitser kan vi nu præsentere her, for de ligger faktisk i Det Kongelige Biblioteks Håndskriftafdeling. Og ikke alene skit-ser til møblerne, men også til andet af billedhuggerens indbo - plus hans tegninger til medaljer, til mønter og til en del af hans skulpturer. Alt dette er af den ene eller anden grund endt blandt vennen, kunsthistorikeren N.L. Høyens papirer, og her har det ligget det sidste halvandet hundrede år.

At disse usignerede udkast virkelig er af Hermann Ernst Freund, fremgår dels af deres forhold til hans kendte færdige arbejder, dels af at de er tegnede på freundske papirer: bag på breve til billedhuggeren og på papirer med Freunds karakteristiske og næsten ulæselige blyantskrift. Hvordan de er 


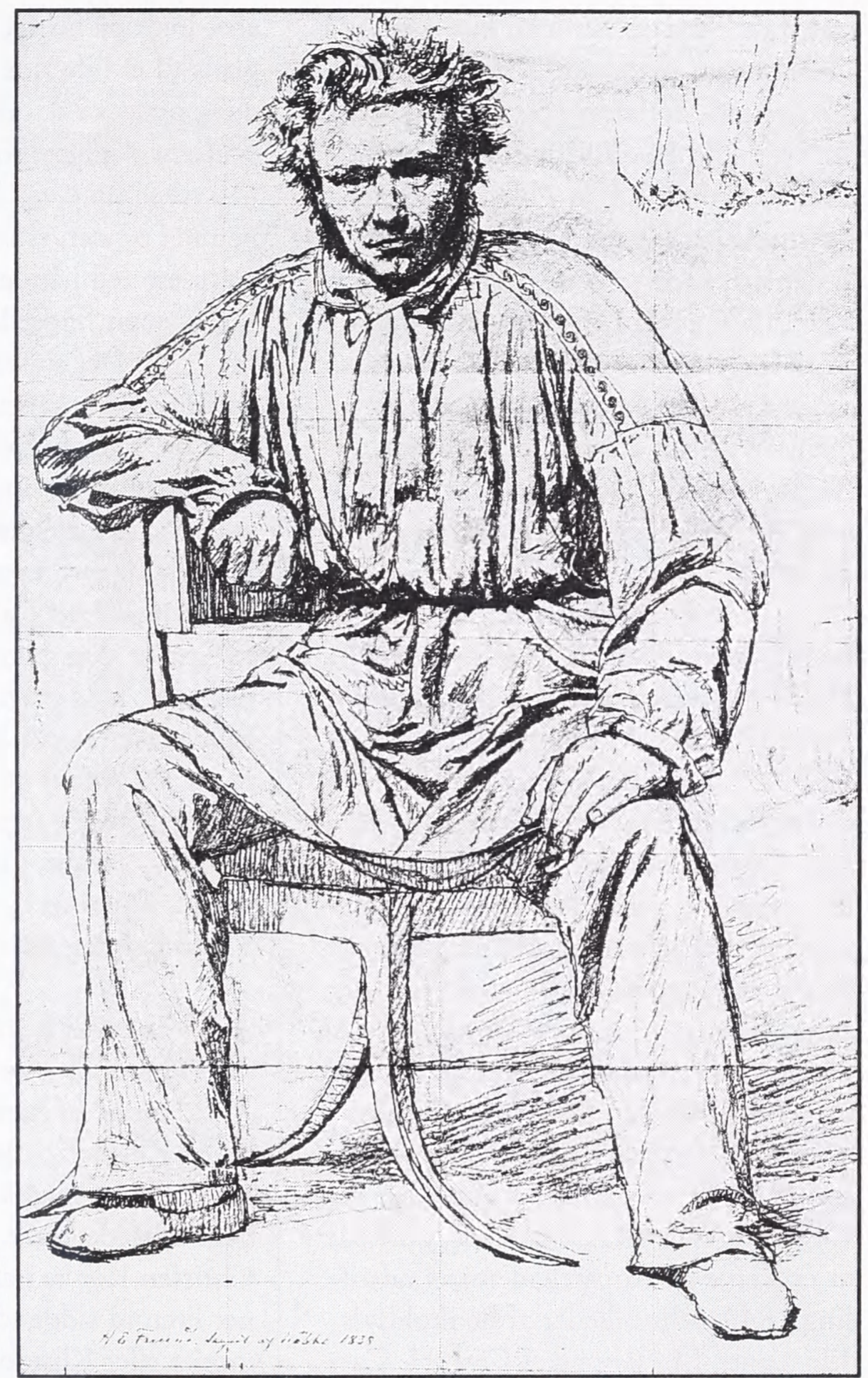

Billedhuggeren Hermann Ernst Freund siddende på en af sine klismos-stole. Tegnet 1838 af Christen Kobke. Den Hirschsprungske Samling. 
endt hos Høyen, kan man kun gætte på - måske som materiale til en afhandling om Freund, der aldrig blev skrevet - måske blot som en erindring om vennen efter hans død. De to - billedhuggeren og kunsthistorikeren - havde lært hinanden at kende som unge studerende i Rom; da Freund kom tilbage til Danmark knyttedes venskabet fastere og siden dannede de sammen med Hermann Wilhelm Bissen det berømte "fredagsselskab", der fik så stor betydning for adskillige af guldalderperiodens kunstnere.

De tegninger, der her skal fremdrages, ligger som sagt blandt N.L. Høyens papirer i et læg med udskriften: Varia, især ang. Arkitektur. ${ }^{3}$ Det drejer sig om 36 af lægets ialt 82 blade, resten er $\mathrm{i}$ egentligste forstand "høyenske papirer". Disse sidste en broget samling af kunsthistorikerens meget grundige iagttagelser vedrørende engelske og franske kirker, tanker omkring malerkunst - og noget uventet: små notater om eksotisk kunst, maori, maya, javanesisk, kinesisk med henvisninger til engelske tidsskrifter om slige sager. En lap papir røber, hvad Høyen som nyansat inspektør ved Den kongelige Maleri-samling ønskede at erhverve på Kunstakademiets udstilling 1840: seks billeder af henholdsvis J.L. Lund, J.L. Jensen, A.Carl, H. Carmienck, J. Mohr og J.A. Krafft; tre af disse genfinder vi i dag i Kunstmuseets katalog over den ældre danske malerkunst. $^{4}$

Lægets freundske papirer med skitser og tegninger er blade i størrelser fra folio til små papirlapper; flere er breve, som Freund har tegnet bag på eller hvor på brevet han nu har fået plads til et lille rids af en ide - en almindelig praksis i datiden, nogle af Thorvaldsens dejligste tegninger er kradset ned på samme vis. Man fik en ide, greb pennen og den stump papir, der var nærmest ved hånden. Papir var ikke noget, man frådsede med - dengang.

Det sidste giver mulighed for en tilnærmelsesvis tidsbestemmelse i de tilfælde, hvor brevene er daterede. For eksempel har Freund tegnet udkast til et gravrelief med en afskedsscene bag på et rørende tiggerbrev af 6. marts 1838 fra en "Privatlehrer Carl F. Gebauer"; han var søn af den gamle dyremaler C.D. Gebauer, hvis gravmonument Freund havde lavet et par år tidligere. Udkastet til en stol sidder på et stykke stempelpapir fra 1833, tegning til et par sølvskeer har fundet plads på et hyldestdigt af F.C. Hillerup i anledning af Frederik VIs fødselsdag 28. januar 1830 etc.

$\mathrm{F}$ or nu at begynde med skitser til Freunds møbler: først til den "fineste" af hans nyantikke stoletyper, Klismos-stolen - dvs. den rent græske form med stærkt fremover- og bagudbøjede ben og buet rygbrædt; Christen Købke har både malet og tegnet Freund siddende på en af sine Klismos'er eller Klismoi, som de vel må hedde i flertal. Professoren havde i hvert fald otte stole af denne art. Blandt papirerne her er der fjorten løse skitser til disse - de fleste blot små rids med mere eller mindre svejede ben, i nogle tilfælde forsynet med en løs pude. Tegningerne virker nærmest som en slags notater: " sådan nogle stole skal vi se at få lavet! “ 


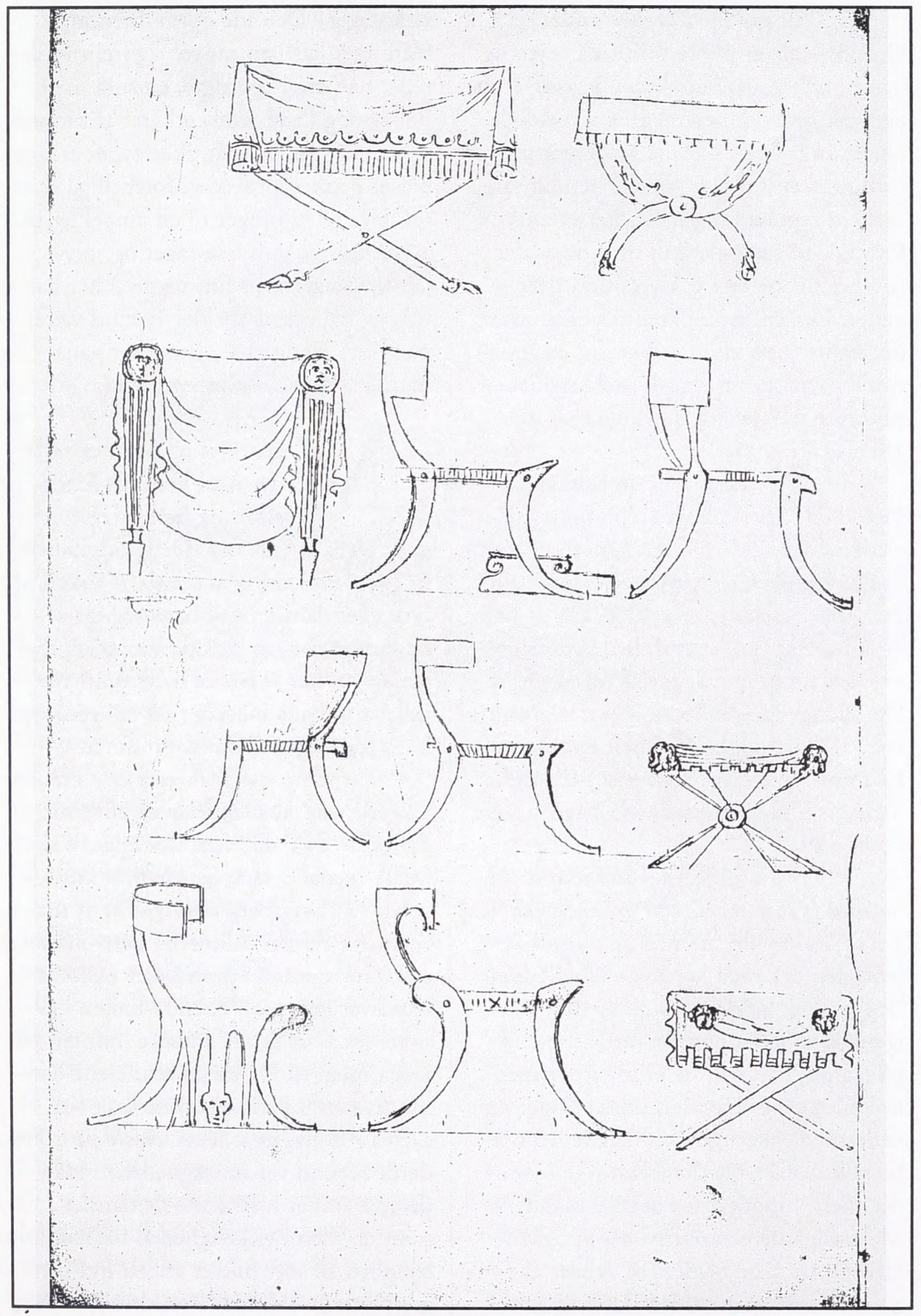

Dette ark med klismos-stole har Freund antagelig tegnet af efter en celdre bog med mobel typer. 
Et ark med blandt andet seks klismos-stole er næste skridt på vejen og har en helt anden karakter - tegningerne er tydeligere og mere gennemarbejdede, her er angivet forskellige løsninger på forbindelsen mellem stolens ben og sarg, mellem rygbrædt og sæde, her er antydet fletværk på sæderne, i et tilfælde er der tilsyneladende lagt et dyreskind over sædet. Det er næppe Freunds egne ideer; det ligner mest af alt kopier fra en mønsterbog, måske en fransk, med nyklassicistiske møbler fra slutningen af det attende århundrede.

Vi ved, at Freund opsøgte ideer i datidens billedpublikationer; han ejede J.K.W. Zahns Die schönsten Ornamente und merkwürdigsten Gemälde aus Pompeji, Herculanum und Stabiä, at han også her har fundet forbilleder for sine møbler, fremgår tydeligt af tegningerne i Det Kongelige Bibliotek. Da det kom til stykket, foretrak han en helt enkel Klismos-type, nært beslægtet med den, maleren Abildgaard i sin tid havde skabt til sig selv.

På samme ark har Freund tegnet fire taburetter af den type, der kaldes cella curulis - de tre med lige-krydsede ben, den ene med krydsede bøjede ben. Begge typer fandtes i hans hjem, men igen: af en langt enklere udførelse end på tegningen, hvor de er forsirede med løvemasker, dyrefødder, udskæringer og sæderne dækket med broderede, frynsebetræk. Sofaen fra det freundske hjem det mest imponerende stykke blandt Materialgårdens møbler - ser vi også blive til på disse blade. To skitser angiver høje svungne sidestykker, som vi kender dem blandt andet fra romerske sarkofager. Den ide opgav Freund, i tegninger har han prøvet sig frem til den type, han endelig valgte, en sofa med høj ryg og flade armlæn båret af broncesfinxer. Stoleben af antikke typer er også blevet gennemprøvede i forskellige skitser. Her er tegninger til en ampel og til andet udstyr som lysestager og sølvbestik. Stagerne er fint tegnet, her har den gamle metalarbejder Freund været på sikker faglig grund, modsat hans mere beskedne møbeltegninger.

9) $1 \begin{aligned} & \text { edarllier og Mynter" står } \\ & \text { der med Freunds hånd- } \\ & \text { skrift og helt private orto- }\end{aligned}$ grafi på et af vore ark. Den gode billedhugger lærte aldrig at stave - hverken på tysk eller dansk. Et af hans vigtige arbejdsområder var netop mønter og medaljer; nu har vi her et halvthundrede udkast til hans medaljer og en tredive af hans tegninger til danske mønter.

Som nævnt overvejede Freund allerede som akademielev at blive medaljør. I 1811 skar han stempler til sin første medalje, få år senere blev han sendt til Kongsberg i Norge for at modernisere møntmaskineriet der; interessen for mønter og medaljer beholdt han livet igennem. Årene i Italien benyttedes til at samle antikke mønter, på vejen hjem til Danmark studerede han møntvæsen i Paris og andre byer - til sidst i Altona, hvor hans ældste bror Frederik Freund var møntguardein. Han drømte om at forskønne de danske mønter, men i virkeligheden fik han kun lejlighed til at forme et enkelt nyt pengestykke: en såkaldt "Zweidrittel" til det lille hertugdømme Lauenburg, som 


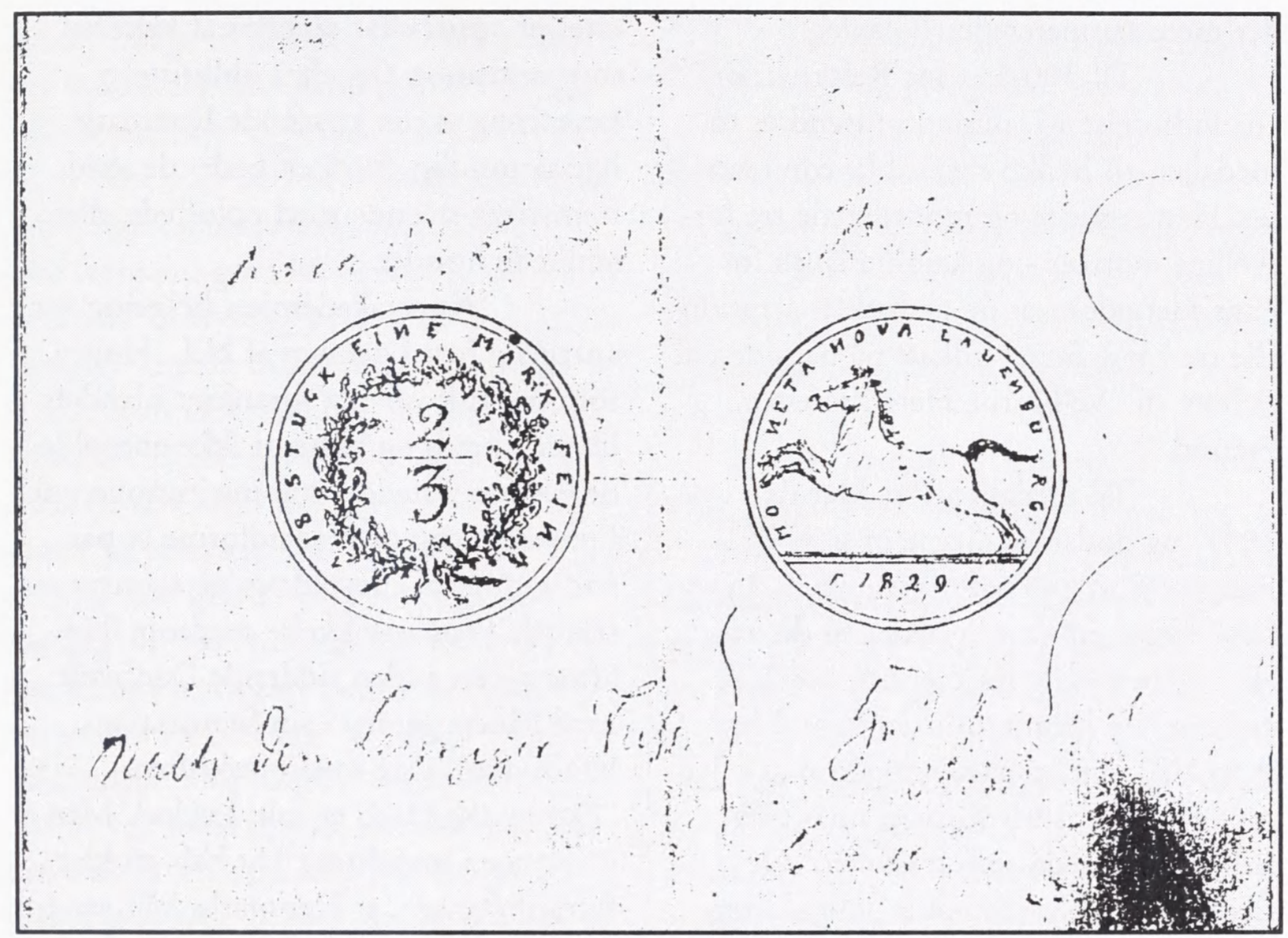

Freunds udkast 1829 til en såkaldt „Zweidrittel“ - en mont der blev slået til hertugdommet Lauenburg.

Danmark fik til en slags erstatning for tabet af Norge. Til den har vi nu en omhyggelig tegning, dog med en anden tekst og forside end den, der 1830 blev slået i Altona.

Efter Frederik VIs død 1839 skulle der naturligvis udarbejdes en ny møntserie med kong Christian VIII.s billede; da Freund selv døde året efter, fik han ikke løst denne opgave, men her blandt hans papirer ligger to blade med 28 udkast til forskellige værdier af specier og skilling til en sådan række Christian VIII-mønter.

Nu kan vi også i disse papirer følge Freunds arbejde som medaljør. Her er idéskitser og fortegninger til alle hans kendte medaljer fra tiden efter hjemkomsten 1828 - alle undtagen én:

medaljen slået i anledning af Frederik VIs 50-års regeringsjubilæum i 1834 . Freund tegnede medaljer, modellerede undertiden store modeller til dem, men overlod andre at skære de fornødne stempler til prægningen. Blandt skitserne finder vi den vingede genius til sølvmedaljen 1831 for de Massmannske Søndagsskoler; til medaljen, der blev udgivet $\mathrm{i}$ anledning af Frederik VIs helbredelse og ankomst til København i 1833, er her en stor omhyggelig tegning. Teksten til medaljens omskrift har Freund fået leveret på en seddel, hvor der står: "Frederik den Siette Folkets Fader Kongestadens Glæde.” Dvs. på sedlen står Kongestadens Jubel, men det har dog været en tand for meget, så "Jubel" er streget over og erstattet med 
det mere tempererede: "Glæde".

Til 300-året for Reformationens indførelse i Danmark udsendtes to medaljer, til hvilke Freund lavede reverser. Han tegnede og modellerede tre forskellige motiver - og karakteristisk for hans iderigdom er de nedfældet samtidig alle tre i løse første udkast på bagsiden af et brev til "Velbaarne Herr Professor Freund."

\section{Til medaljen Pro Meritis} 1837, og dødsmedaljerne over A.W. Hauch 1838 og Frederik VI 1839, ligger forskellige udkast - ligeledes til de to allersidste forslag fra Freunds hånd, reverser til en kroningsmedalje for Christian VIII. De to nåede dog kun at blive modellerede i stort format, men blev aldrig realiserede som medaljer. ${ }^{6}$ De fremkom på en tidstypisk politisk baggrund; Freunds søn, Victor Freund har fortalt historien bag dem i sin bog om faderens levned. ${ }^{7}$ Kongen havde selv bestemt både motivet og hvad der skulle stå på medaljen, den skulle vise Danmark i form af en kvindeskikkelse knælende i bøn for majestæten og have omskriften: GUD VELSIGNE KONGEN. Men her i enevældens allersidste årti var et knælende Danmark næppe den bedst mulige ide til en kongelig hyldestmedalje, så da Christian VIII sendte sit forslag til udtalelse i Kunstakademiet, fik han det retur med bedømmelsen: ubrugeligt!

Akademiet benyttede naturligvis alene en formel begrundelse for sin afvisning: at motivet var uden hjemmel i antik tradition: en knælende kvindeskikkelse var (er) efter antikkens forestilling altid en provins, der tages til nåde efter et oprør eller opløftes af kejseren som restitutor. Og efter oldkristelig tankegang var et knælende Danmark lige så umulig, fordi en bedende altid fremstilles stående med opløftede eller sænkede hænder.

Kunstakademiets belæring var antagelig ført i pennen af N.L. Høyen, som politisk var fast forankret i landets liberale kreds og bestemt ikke enevoldsbegejstret. I stedet satte institutionen så Freund i gang med at udforme et par andre mindre enevoldsagtige motiver: en stående Dania-skikkelse med oprakte arme og en anden siddende Danmark med håbets genius i sin fremstrakte hånd, den sidste med omskriften: "Danmarks Haab er min Lykke". Men da kongen utvivlsomt har haft en klar forestilling om, at Danmarks håb var en fri forfatning, gjorde disse forslag ham ikke synderlig begejstret.

Christian VIII var dog endnu enevoldskonge, så han fik den medalje, han ville have; han henvendte sig simpelthen til Thorvaldsen, som formodentlig var komplet uinteresseret i dansk politik - enevælde eller ikke enevælde og vor berømte billedhugger leverede kongen et knælende Danmark i bøn med den oprindelige omskrift, Gud velsigne Kongen. Resultatet var dog meget jævnt efter thorvaldsensk standard.

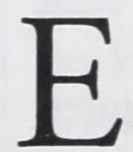

ndelig ligger der i de freundske papirer en del tegninger til en medalje med gudinden Ceres og en plov; den har årstallet 1829 og må altså være en af de første opgaver af den art, kunstneren arbejdede med, efter han var 
vendt tilbage til Danmark. Motivet findes imidlertid ikke på nogen af Freunds kendte medaljer og hvad den var tænkt til, er ikke godt at vide - måske til Det kongelige Landhusholdningsselskab, hvis formand gennem mange år var Freunds "beskytter" Jonas Collin. I 1859 - mange år efter billedhuggerens død lavede hans elev, Harald Conradsen for Landhusholdningsselskabet en hyldestmedalje til Collin med dette Ceresmotiv på reversen. Der kan være en sammenhæng mellem denne Collinmedalje og Freunds tegning; som elev har Conradsen været tæt på sin lærer og vel orienteret om hans arbejder. Freund uddannede flere unge medaljører; efter han havde overtaget sit professorat, sendte Kunstakademiets præses, prins Christian Frederik (den senere Christian VIII) billedhuggerne Christen Christensen og F.C. Krohn til hans atelier for at uddanne dem til medaljører; senere fulgte Conradsen efter.

De tegninger, vi nu kender til Freunds medaljer, lader os følge hans arbejde fra ide til det færdige værk. For en klassicistisk kunstner som ham forelå et givet repertoire af symbolske gudinder, genier og lignende til den slags opgaver. Problemet var at anbringe dem meningsfuldt og harmonisk på medaljens lille runde flade. Vi kan se, at selve ideerne oftest har ligget fast fra starten, forandringerne kan være forenklinger, en overflødig figur forsvinder undervejs (på Christian VIIIs kroningsmedalje), en profilfigur vendes fra højre mod venstre (Frederik VIs dødsmedalje), i andre tilfæ̣lde er forandringerne minimale.
$\mathrm{T}$ il sidst skal omtales en del blade med skitser til skulpturarbejder. I sig selv - som tegninger - er disse uden større interesse, Freund var desværre en påfaldende elendig tegner, når det drejede sig om andet end rent ornamentale sager - figurer voldte ham de største vanskeligheder at få ned på papiret.

Ofte er skitserne også tegnet både småt og gnidret; meterhøje gravmonumenter dukker op på papiret som et første ideudkast på et par centimeters højde, de halvtredie meter brede reliefmedaljoner, han lavede til loftet i Holmens kirke, finder vi her som ganske små skitser, nogle meget beskedne småtegninger bag på en glarmesterregning fra 1839 er allerførste studier til de to kapitæler på forsiden af Thorvaldsens Museum, som Freund lavede samme år. Som selvstændige kunstværker er sådanne tegnerier altså ikke meget bevendt, men spændende som visuelle spor af billedhuggerens vej mod et færdigt kunstværk.

De fleste er udkast til gravmonumenter. Når Freund lidt bitter gjorde status over de store opgaver, han ikke fik, sagde han, at hans arbejde var reduceret til at klappe gravene over de døde. Han følte - som rigtigt var - at hans billedhuggergerning hovedsagelig bestod $i$ at lave gravsteler og mindesmærker. Heldigvis lavede han dem ualmindeligt smukke i de gamle grækeres spor.

Blandt papirerne ligger adskillige vidnesbyrd om denne del af Freunds virksomhed, for eksempel sedler som denne med efterladtes ønske om ind- 
skriften på det bestilte gravmæle:

Herunder hviler de jordiske Levninger af

Amalia Salomonsen født Henriques død i sit 59 e Aar den 15 de Juny 1835

Fred være med hendes støv

Sedlen har Freund vendt om og på bagsiden lavet et første beskedent udkast til en mindesten. ${ }^{8}$ En gravstele over Amalia Salomonsen findes imidlertid ikke i Th. Oppermanns fortegnelse? over kunstnerens arbejder, men den var måske værd at lede efter. En Amalia Salomonsen født Henriques, død 1835 kan vi let finde som Malchen (Malka) Henriques gift med urtekræmmer Samuel Moses Salomonsen. Så består den videre kunsthistoriske forskning $\mathrm{i}$ at spadsere en tur ud til den mosaiske nordre begravelsesplads i Møllegade på Københavns Nørrebro. Og der står ganske rigtig en typisk Freund-stele med ovennævnte indskrift. En enkel slank sandsten, kun smykket af en stor palmet i stelens øverste felt. Så nu har papirerne i Det Kongelige Biblioteks Håndskriftafdeling altså sikret os et hidtil ukendt arbejde af Freund! ${ }^{10}$

En anden indskrift til et gravmæle har professoren modtaget fra sin akademikollega Just Mathias Thiele, utvivlsomt på foranledning af dennes svigerfar, senere geheimekonferensråd Nicolai Abraham Holten. Holten ejede Krabbesholm og Sæby kirke ved Roskilde fjord, og det var ham, som lod monumentet rejse over “- en gudfrygtig Christen, Gaardmand Lars Pedersen af Sæbye." Holten nævnes sidst i indskriften som Krabbesholms ejer, der savner og mindes afdøde. Gårdmandens gravmæle på Sæby kirkegård er smykket i gavltoppen af et neg, en rive og en le; tegninger af en plov blev brugt til monumentet over en anden jordbruger, godsejer Christian Frederik Fiedler, som blev begravet på Tjæreby kirkegård ved Skelskør.

Som sagt var vores billedhugger en ualmindelig sløj tegner, alligevel kan vi dog genkende et græsseligt kradseri som en første ide til mindestenen for overlærer på Herlufsholm, Hans Bøchman Melchior. Det forestiller en siddende lærer og to stående disciple; ved at placere dem sådan i forhold til hinanden, har Freund opnået en komposition med figurernes hoveder $\mathrm{i}$ samme højde på klassisk vis. På tegningen holder en af disciplene en skolebog $\mathrm{i}$ hånden, bogen er strøget i det endelige relief, men den genreagtige ide blev genbrugt 1837 til det meget lignende relief på stenen til distriktskirurg Heinrich Friederich Müller på Skelskør kirkegard. De to skolebørn på lægens gravstele hentyder til Sorø Akademi som Müller hovedarving. Tegninger af dødsengle, afskedsscener etc. er allesammen vidnesbyrd om Freunds overvejende beskæftigelse med at "klappe de dødes grave."

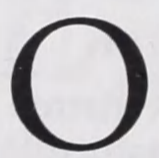
gså Freunds virke som skulpturrestaurator har sat sig spor i de freundske papirer. 1831 havde Rentekammeret bedt ham tage sig af tilsyn og vedligeholdelse af Johannes Wie- 


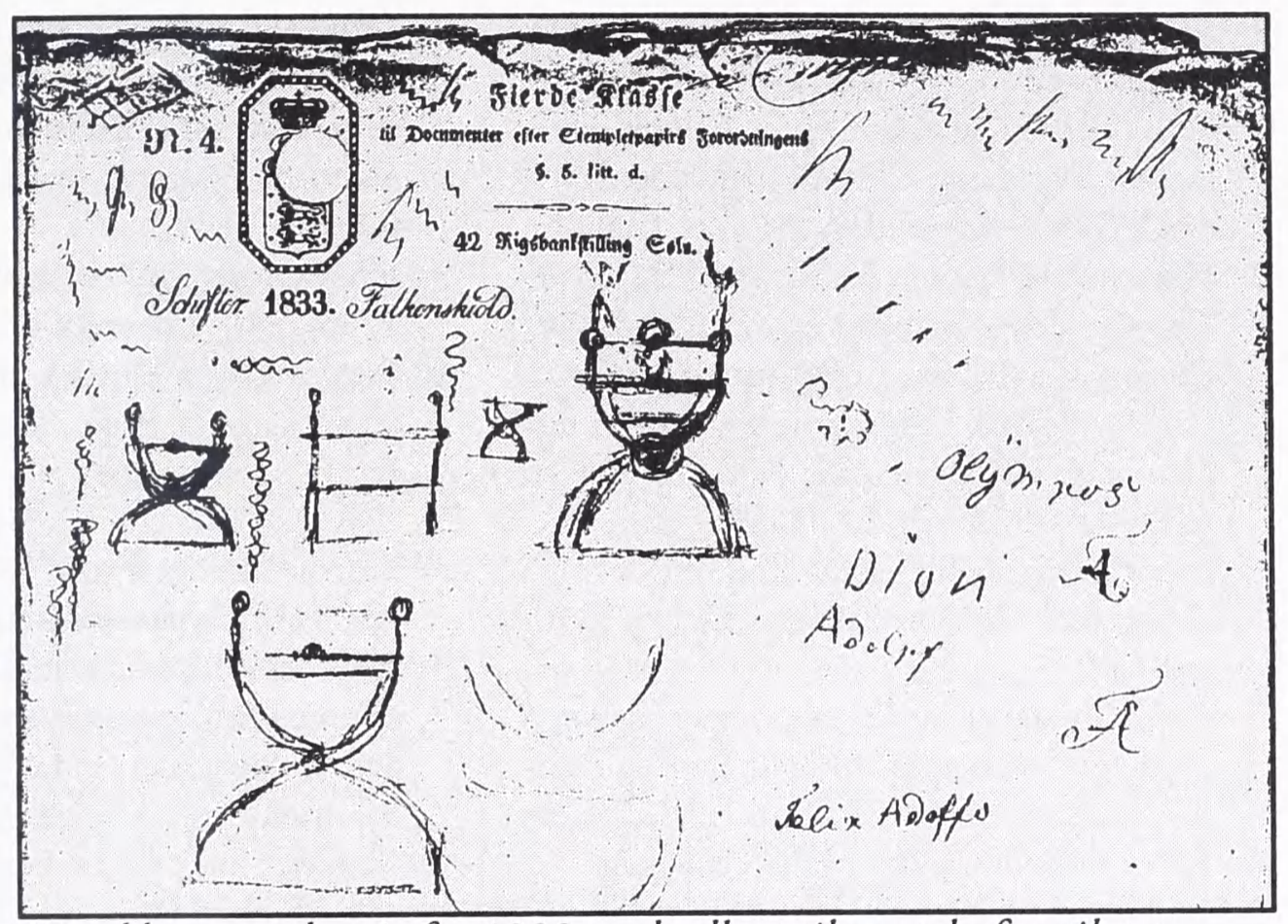

Et stykke stempelpapir fra 1833 med udkast til en stol af antik type.

dewelts mange nationale mindestøtter i Jægerspris slotspark. De var hugget af norsk marmor i 1770 - 80erne og i tidens løb slemt forvitrede. Freund erstattede efterhånden nogle af disse med nye.

Et ark papir, sammenfoldet så det kunne stikkes i lommen, har nogle kryptiske blyantsnotater, der røber, at han har været en tur i Fredensborg park og set til figurerne der også. Og han har haft travlt! For de næsten ulæselige noter ligner mest af alt en slags privat stenografi. Man læser dog ord som: Normandsdale, og derunder kan tydes noter som: Mangler 1 Finger, Mangler en Arm, takker paa Kronen, Bergens Stift etc. Formålet med Fredensborgturen har øjensynligt været at foreslå restaurering af slotsparkens skulpturer blandt andre billedhuggeren J.G. Grunds fiskere, bønder og andre af Frederik V.s norrøne undersåtter. som står i Nordmandsdalen.

Andre Fredensborg-lokaliteter, som nævnes, er Balon (Ballonpladsen) Rostra paa Skibsbakken, Marmorhaven og igen ... at rense for mos, mangler et stykke af ansigtet, hagen, et stykke af kroppen, næser, ørerne, mangler en finger og lignende. Navnlig fingrene synes at være gået meget ondt igennem. Det er tydeligt, at her har været brug for en omfattende kirurgisk hjælp fra en skulpturkonservator. Ved de enkelte blessurer har Freund skrevet: $1 \mathrm{~d}, 2 \mathrm{~d}$ eller 2 Dage, 8 Dage - den fornødne tid til at lave en ny finger eller anden transplantation. En mængde tal og beregninger på samme ark er måske en eller anden form for estimation over omkostningerne, selv om tallene er temmelig uigennemsigtige.

De nyfundne papirer i Høyens arkiv kan således på flere måder udbygge vort kendskab til sider af Hermann Ernst Freunds arbejde i årene efter han var vendt tilbage til Danmark. Det var godt, Høyen i sin tid tog dem til sig. 
1 Mirjam Gelfer-Jørgensen red.: Herculanum paa Sjælland. København 1988, p. 91.

2 Erik Lassen: Kunstnerhjem og Kunstnermøbler; i Bo Lindwald red: Guldalderen i dansk Kunst. København 1964, p. 134.

3 N.L.Høyens Papirer. NKS 1553, $2^{\circ}$,

4 De pågældende malerier var: J.L.Lund: En Skovegn, J.L.Jensen: Et Blomstermaleri, A. Carl: Lyng-Egn; i det Fjerne sees Altona og Hamborg, H.Carmiencke: Parti i de böhmiske Riesengebirge, J.A. Krafft: Scene af Landsby-Familieliv i Tydskland. J.Mohr: Udsigt over Havet ved den holstenske Kyst nær Kiel.

5 De tre modeller til Reformationsmedaljen er på Ny Carlsberg Glyptotek; katalog Danske Skulpturer 1694-1889 nr. 12l-122-123

6 De to modeller findes på Ny Carlsberg Glyptotek; op.cit. nr. 140-141

7 Hermann Ernst Freunds Levnet. Ved Victor Freund, udgivet af H.R. Baumann. København 1883 , p. $237 \mathrm{ff}$.
8 Den ganske lille skitse har ingen lighed med Amalia Salomonsens gravsten, men langt snarere med monumentet over grev Schimmelmann i Jægersprisparken, som Freund fornyede 1838.

9 Th. Oppermann: Hermann Ernst Freund 1786-1840. København 1916.

10 Stenen står på Mosaisk nordre begravelsesplads, karré $\mathrm{H}$, gang 2, nr. 4. En kopi af Freunds stele er rejst over hendes mand, der døde 1855 og blev begravet ved siden af sin hustru. Yderligere to af Freunds gravsteler står på begravelsespladsen den ene over bogholder Moses Levin Abrahams (1832) af samme form og udsmykning som Amalia Salomonsens, den anden over hofgravør Salomon Aron Jacobson (1835) . En gravsten over Isaak G. Levysohn er fuldstændig af "freundsk" form; men den begravede er død i 1849 , så enten har han faet lavet sin gravsten i god tid, eller også er den hugget efter freundsk forbillede. 